\title{
An unusual rhino-pharyngeal foreign body
}

\author{
*P. A. Onakoya, A. A. Adoga ${ }^{1}$, A. S. Adoga ${ }^{1}$, \\ C. Galadima ${ }^{1}$ and O. G. B. Nwaorgu \\ Department of Otorhinolaryngology, College of Medicine, \\ University College Hospital, Ibadan and \\ 'Ear, Nose and Throat Unit, Department of Surgery, \\ Jos University Teaching Hospital, Nigeria. \\ E-mail: ponakoya@comui.edu.ng
}

\begin{abstract}
Summary
Background: Foreign bodies of the upper aerodigestive tract are commonly seen in the paediatric population; however adult patients with nasal foreign bodies in particular are much less common and when sharp foreign bodies are present there is a great risk of developing complications.

Study design: This is a case report of a 20-year-old male magician with impacted rhino-pharyngeal foreign body. He intentionally inserted two long sewing needles into the right nasal cavity during a magical act.

Results: The impacted foreign bodies were located in his nose/pharynx and removal was achieved per orally under general anaesthesia. Only a minimal evidence of retropharyngeal abscess was noted despite the prolonged stay of the foreign bodies.

Conclusion: This case highlights the fact that both a deliberate and an accidental foreign body in an adult nasal cavity can get impacted as well as the significance for its early removal.
\end{abstract}

Key words: Adult, Foreign body, Needles, Nose, Pharynx, Transoral, Magician.

\section{Résumé}

Introduction: Corps étranger dans le tube aérodigestif supérieur sont le plus sovent vu chez la population pédiatrique; toutefois, des patients adultes avec des corps étranger nasals en particulier sont peu courants et quand il y a des corps étranger bien actifs un grand risque du développement des complications sont provoquées.

Grandes lignes d'études: Il s'agit d'un rapport d'un cas d'un magicien âgé de 20 ans atteint d'un corps étranger rhinopharyngite incogruence. Il avait intentionnellement enfoncé deux aiguilles à coudre longue dans la fosse nasale de la droite au cours d'une action magique.

Résultats: Corps étranger enfoncés ont été situés dans son nez et on avait effectué l'enlèvement par voie orale sous l'anesthésie générale. On avait noté seulement une preuve minime d'abcès rétropharynigite en dépit d'un sejour prolongé des corps étranger.

Conclusion: Ce cas souligne le fait qu'un corps étranger voulu ou accidentel, les deux, dans la fosse nasale d'un adulte peut être barré, il souligne aussi l'importance de son enlèvement précoce.

\section{Introduction}

Foreign bodies of the upper aerodigestive tract in the paediatric population are a common occurrence ${ }^{1}$. They are most often accidentally or deliberately inserted especially in mentally retarded patients who may revert to this childhood behavior and of children commonly less than five years of age $^{2,3}$. Foreign bodies are either animate or, more often inanimate objects such as beads, cotton wcol, button, particles of food, candy, toy parts, pebbles, and paper inserted into one or both nostrils ${ }^{3-5}$.

Nasal foreign body in the adult is rare but when present may mimic a rhinolith. Rhinoliths, which are re re and may occur after occasional introduction of a for eign body consists of layers of calcium and magnesium silts formed around a central nucleus. Clinical presentations are varied ${ }^{6,}$ 7. These foreign bodies usually lodge on the floor of the anterior or middle third of the nasal cavity and may constitute Otolaryngological emergencies.

This is a case report of a magician with impe cted rhinopharyngeal foreign body.

\section{Case report}

HY, a 20-year-old male magician preser ted to the

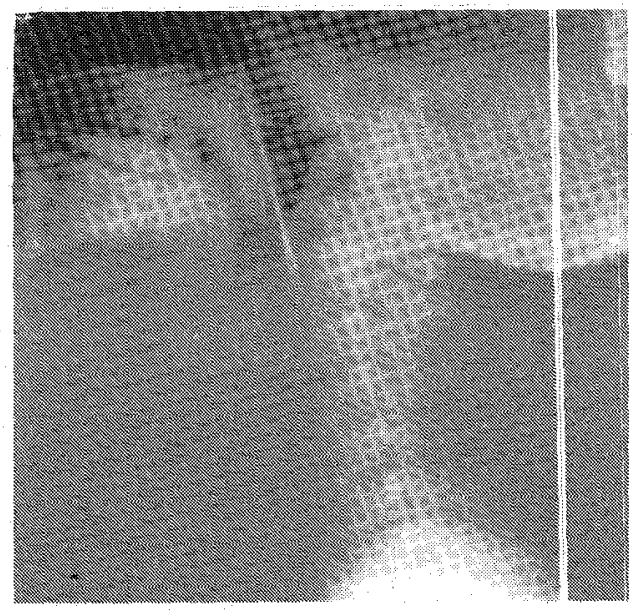

Fig. 1 Lateral view of the X-ray soft tissue neck, showitg the lower end of the foreign bodies within the normal previrtebral soft tissue at the level of the 2nd cervical vertebral bo ly. Cervical lordosis is maintained.

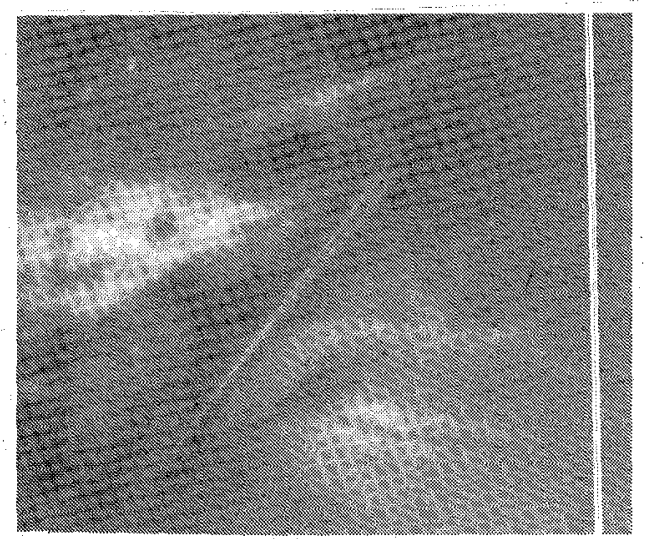

Fig. 2 The lateral view of the $X$-ray sinuses showing the breign bodies within the nasal cavity, with their tips towarls the roof of the cavity. 


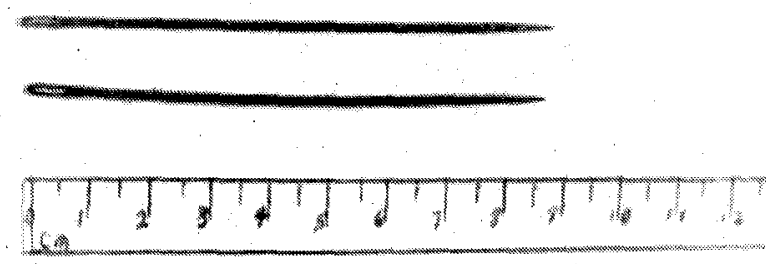

Fig. 3 The extracted foreign bodies (sewing needles), which are about $9 \mathrm{~cm}$ long each when measured.

Accident and Emergency Department of the Jos University Teaching Hospital with a month's history of having intentionally inserted two long sewing needles into the right nasal cavity during a magical act which he found difficult to remove later despite several attempts.

There was initial epistaxis, provoked by blowing of the nose, which stopped spontaneously after a week, and associated bilateral nasal blockage with mucoid discharge. No other nasal symptoms were experienced. He also had associated odynophagia and dysphagia to solid and liquids, lowgrade intermittent fever, and neck stiffness, two weeks before presentation. There was no history suggestive of mental illness in the past

Physical examination revealed an apprehensive young man who was not febrile. The ear examination was essentially normal. Anterior rhinoscopy revealed engorged inferior turbinates bilaterally, with hyperaemic nasal mucosa. No foreign body was visualised. The nasal cavities were patent. Posterior rhinoscopy revealed hyperaemic and oedematous right posterior choana. The lower ends of two metallic objects were impacted in the retropharyngeal soft tissue of the nasopharynx with fullness of the area.

Throat examination essentially revealed slight fullness of the right posterior pharyngeal wall with diffuse hyperaemia of the mucosa. There were no palpably enlarged and tender neck nodes.

Plain radiograph of the soft tissue neck and sinuses confirmed the clinical findings (Figures 1 and 2). The two radio opaque objects were seen extending from the roof of the nasal cavity down to the level of the second cervical vertebral body with the lower end embedded in the prevertebral soft tissue. The haematological investigations were all within normal ranges.

Under anaesthesia a longitudinal incision (about $1.5 \mathrm{~cm}$ ) was made over the point of impaction into the posterior pharyngeal wall with very minimal pus drained; the foreign bodies were then teased out towards the hypopharynx until their tips were seen in the oropharynx, and delivered through the mouth. Each needle measured approximately 9 centimetres in length (Figure 3 ).

He had parenteral antibiotics and analgesics post-op- eratively for 24 hours and thereafter orally together with nasal decongestant with remarkable improvement in his clinical status. He also had anti-tetanus prophylaxis. Consult to the Psychiatrist was made but the patient absconded from the hospital before he could be reviewed on the second postoperative day.

\section{Discussion}

Many of the foreign bodies seen in adults are due to either mental retardation or deliberate either as charm or selfharm as in suicidal attempts ${ }^{2,3,8}$. Salley and Woh $1^{9}$ described a particular case of a woman who presented with metallic foreign body, an open safety pin lodged in her left nostril. Foreign bodies in the aerodigestive tract tend to present earlier and more promptly removed compared with ear and nose foreign bodies ${ }^{1}$.

The single biggest clue to diagnosis of a nasal foreign body is a unilateral nasal discharge or obstruction ${ }^{3,4}$. Indeed, if this is found, the patient should be considered to have a nasal foreign body until proven otherwise, especially in children. A nasal foreign body carries the danger of inhalation into the lungs and subsequent formation of a lung abscess. This was not the case in our patient as the length of the sewing needles made it difficult to negotiate from the posterior choana to the nasopharynx with resultant impaction.

Older patients with sharp foreign bodies are at great risk of developing complications ${ }^{10}$. Acute retropharyngeal abscess may result from penetrating injury or foreign bodies piercing the posterior pharyngeal wall of upper aerodigestive tract especially in older patients ${ }^{10,11}$. The patient will most often present with, history of fever, throat or nose infection, difficulty in swallowing, and nasal obstruction in case of abscess extending up to nasopharynx as observed in our patient.

The diagnosis of foreign body in the nose is usually made by inspection of the nares. The nostril in which the foreign body is impacted depends on the handedness of the patient and is found to be of higher proportion in the right nostrils ${ }^{12}$. Examination of the nasopharynx with a mirror may be appropriate in adults but is difficult in children. Radiographs of the nose are often recommended but are more helpful in checking for surrounding sinusitis and are of little value when radiolucent foreign bodies are involved.

Most of the time, patient is at risk of injury and possible aspiration from clumsy attempts at removal by an unskilled person. Any attending physician should not attempt removal without appropriate instruments and good control of the patient.

This case highlights the fact that both a deliberate and an accidental foreign body in an adult nasal cavity can get impacted as well as the significance for its early removal.

\section{References}

1. Koempel JA and Holinger LD: Foreign bodies of the upper aerodigestive tract. Indian J Pediatr 1997; 64: 763 - 769.

2. Kalan A and Tariq M: Foreign bodies in the nasal cavities: a comprehensive review of the aetiology, diagnostic pointers, and therapeutic measures. Postgrad Med J 2000; 76: 484 487. 
3. Werman HA: Removal of foreign bodies of the nose. Emerg Med Clin North Am 1987; 5: 253 - 263.

4. Francois M, Hamrioui R and Narcy P: Nasal foreign bodies in children. Eur Arch Otorhinolaryngol 1998; 255: 132 - 134.

5. Kadish HA and Corneli HM: Removal of nasal foreign bodies in the pediatric population. Am J Emerg Med 1997; 15: 54 56.

6. Vink BW, van Hasselt $P$ and Wormald $R$ : A case of rhinolithiasis in botswana: a mineralogical, microscopic and chemical study. J Laryngol Otol 2002; 116:1036 - 1040.

7. Hadi U, Ghossaini $S$ and Zaytoun G: Rhinolithiasis: a forgotten entity. Otolaryngol Head Neck Surg 2002; 126: 48 - 51 .

8. Loh FC and Ling SY: Analysis of the metallic composition of orofacial talismans. Oral Surg Oral Med Oral Pat nol 1992; 73: $281-283$.

9. Salley LH and Wohl DL: Nasal foreign body: nmoval of an open safety pin from the left nostril. Ear Nose T/ rroat J 2000; 79: $118-120$.

10. Singh B, Kantu M, Har-EI G and Lucente FE: Complications associated with 327 foreign bodies of the pharyny, larynx, and esophagus. Ann Otol Rhinol Laryngol 1997; 106: $301-304$.

11. Poluri A, Singh B, Sperling N, Har-El G, I ucente FE. Retropharyngeal abscess secondary to penetratin ; foreign bodies. J Craniomaxillofac Surg 2000; 28: 243-24i.

12. Hon SK, Izam TM, Koay CB, Razi A. A Prospec tive Evaluation of Forcign Bodies Presenting to the Ear, Nos: and Throat Clinic Hospital, Kuala Lumpur. Med I Malaysia 2001; 56: $463-470$ 